\title{
Application of Gas Chromatography - Flame Ionization Detection to Study Cellular Incorporation of Dietary Trans Fatty Acids of Medical Importance
}

\author{
Anna Somogyi', Judit Mátyási², Zsófia Gór-Nagy², Farkas Sarnyai', Miklós Csala', Blanka Tóth²* \\ 1 Department of Molecular Biology, Institute of Biochemistry and Molecular Biology, Faculty of Medicine, Semmelweis University, \\ H-1428 Budapest, P.O.B. 2, Hungary \\ 2 Department of Inorganic and Analytical Chemistry, Faculty of Chemical Technology and Biotechnology,Budapest University of \\ Technology and Economics, H-1521 Budapest, P.O.B. 91, Hungary \\ * Corresponding author, e-mail: tblanka@mail.bme.hu
}

Received: 11 June 2020, Accepted: 16 September 2020, Published online: 02 February 2021

\begin{abstract}
Putative health effects of dietary trans fatty acids (TFAs) receive a growing attention; while very little is known about the metabolism of these special food components. In vitro studies carried out in cultured cells provide an efficient and standardizable approach to follow the metabolic fate of TFAs, but it requires suitable techniques for the quantitative measurement of FAs in cell samples. Here, the development and validation of a simple and reliable method for the quantification of a group of relevant FAs by gas chromatography and flame ionization detection is presented. Sample preparation used a fast one-step and chloroform-free process for simultaneous extraction and esterification, and chromatographic separation was achieved in 25 min using a Zebron ZB-88 capillary column. A linear calibration (of $R^{2}>0.99$ ) was obtained in the concentration range of $1-200 \mu \mathrm{g} / \mathrm{mL}$ for each $\mathrm{FA}$. Recovery rate was $82 \%$ for samples of non-esterified FAs and $>95 \%$ for complex lipids, such as ceramides, diglycerides and triglycerides. The LOD and LOQ were below $0.5 \mu \mathrm{g} / \mathrm{mL}$, and a robust method precision was achieved (RSD \% was below $6 \%$ for each lipid classes). The present method was also tested on a cultured cell line with or without FA treatment at close to physiological concentration, and the observed changes in the metabolite concentration levels revealed characteristic differences between the metabolism of cis and trans unsaturated FAs.
\end{abstract}

Keywords

cell culture, fast method, method validation, trans fatty acid

\section{Introduction}

Recently, increasing attention has been focused on the health effects of dietary trans fatty acids (TFAs) with special emphasis on the role of these food components in the development of cardiovascular diseases, cancer and diabetes. Living organisms incorporate FAs into a wide variety of complex lipids, including phosphoglycerolipids and sphingolipids forming the bilayers in the cellular membranes, and also triglycerides for a fuel storage [1]. The depot fat is stored in the adipocytes in form of lipid droplets and its triglyceride molecules contain endogenously synthetized FAs as well as FAs ingested with natural or hydrogenated plant oils [2, 3] or animal fat [4]. The optimal physical properties of biological membranes and fat depots requires a balanced utilization of both saturated and unsaturated FAs [5]. The cellular enzymatic systems designed to provide the latter by inserting double bonds into the hydrocarbon chains of FAs are stereospecific and invariably yield unsaturated FAs of cis configuration. Although the trans isomers cannot be endogenous, they are ingested and they appear in the human diet from two sources. The TFAs, mostly vaccenate (C18:1 trans- $\Delta 11)$ can be produced by bacteria in ruminant animals and taken up by humans with dairy products and the meat of these animals [6]. Alternatively, TFAs, mostly elaidate $(C 18: 1$, trans- $\Delta 9)$ can be formed as by-products of industrial food processing, primarily during hydrogenation of plant oils [7].

Due to some in vivo studies reporting the adverse health effect of dietary TFAs [8-11], the maximum trans fat content of food products is regulated in many countries $[12,13]$. However, the increasing number of controversial in vivo studies did not unequivocally support the 
correlation between TFA consumption and human pathologies [14-16]. It is, therefore, essential to study the metabolism and cellular effects of TFAs in vitro in cellular experiments at molecular level [17, 18].

Gas chromatography is a common method employed to analyze the FA composition of different matrices such as foods or biological samples. Saponification allows the determination of a FA profile that includes both the non-esterified molecules and those incorporated in various complex lipids. After alkaline hydrolysis, liberated FAs are usually (re)esterified with a low molecular weight alcohol in order to yield volatile molecules, and also to avoid the formation of hydrogen bonds between the analytes and the stationary phase. The sample preparation method developed by Folch et al. [19] provided an excellent basis for the extraction of lipids from biological samples. Extraction was carried out using a chloroform/methanol mixture in several studies [20-23], and esterification was performed with or without a separate saponification step [22-25]. Alkaline saponification does not lead to a chemical equilibrium, thus the conversion is near to $100 \%$, and the fatty acid methyl esters (FAME) along with the non-esterified FAs can be easily trans-esterified or esterified in the next, acidic reaction $[22,23]$.

The GC-FID or GC-MS instruments are suitable for the chromatographic separation and detection of volatile compounds such as ketone bodies [26], alcohol derivatives [27] or FAME species $[28,29]$. The chromatographic separation of cis and trans (FAME) needs the application of special stationary phases such as propyl-nitrile-polysiloxane [27, 30].

We aimed to develop and validate a sensitive, reproducible and precise GC-FID method with a simple and fast combined extraction and derivatization process followed by an evaporation step, which is suitable for the determination of saturated and cis- or trans-unsaturated FAs, including those incorporated into complex lipids, from cultured cells. After validation, the method will be tested by assessing the effects of palmitate, oleate, elaidate or vaccenate treatments at close to physiological concentration on the FA composition of RINm5F rat insulinoma cells.

\section{Materials and methods}

\subsection{Chemicals and reagents}

Supelco 37 Component FAME Mix (Cat. No.: CRM47885), trans-vaccenic acid methyl ester (Cat. No.: CRM46905), rac-glycerol-1,2-dipalmitate (Cat. No.: SLBN1244V), glycerol-trioleate (D2135), methyl-palmitoleate (Cat. No.: P9667), sodium hydroxide pellet (S5881), boron trifluoride methanol complex solution (61626), sodium chloride (S9625) were purchased from Sigma Aldrich, C18:0 Ceramide was bought from Avanti Polar Lipids, methanol was purchased from Merck, and n-hexane was bought from Romil. All experiments and measurements were carried out by using Millipore ultrapure water (Milli-Q Direct 8 purchased from Merck; 18.2 M $\Omega . c m$ at $25^{\circ} \mathrm{C}$ ).

\subsection{Cell cultures}

RINm5F rat insulinoma cells were purchased from ATCC (CRL-11605) and cultured in RPMI 1640 medium, containing $2 \mathrm{mM}$ L-glutamine, $1.5 \mathrm{~g} / \mathrm{L}$ sodium bicarbonate, $4.5 \mathrm{~g} / \mathrm{L}$ glucose, $10 \mathrm{mM}$ HEPES and $1 \mathrm{mM}$ sodium pyruvate and supplemented with $10 \%$ fetal bovine serum and $1 \%$ antibiotics (Thermo Scientific), at $37^{\circ} \mathrm{C}$ in humidified atmosphere containing $5 \% \mathrm{CO}_{2}$.

\subsection{Cell treatment with fatty acids}

Treatment of the cells with albumin-conjugated palmitate was based on our previous studies [17, 18]. Briefly, palmitate, elaidate, oleate and vaccenate (Sigma) were diluted in isopropanol (Molar Chemicals) to a concentration of $50 \mathrm{mM}$, conjugated with $4.16 \mathrm{mM}$ fatty-acid-free BSA (Sigma) in $1: 4$ ratio, at $37^{\circ} \mathrm{C}$ for $1 \mathrm{~h}$. The working solution for FA treatments was always prepared freshly in FBS-free and antibiotic-free medium at $50 \mu \mathrm{M}$ final concentration. Control cells were treated only with BSA but without any FA. The culture medium had been replaced by FBS-free and antibiotic-free medium for $1 \mathrm{~h}$ before the cells were treated with FAs for $6 \mathrm{~h}$ at $70-80 \%$ confluence in 6 -well plates.

\subsection{Sample preparation - extraction}

At $70-80 \%$ confluence, cells were harvested in $100 \mu \mathrm{L}$ of PBS by scrapping, then were centrifuged in a benchtop centrifuge $\left(5 \mathrm{~min}, 1500 \mathrm{rpm}, 4^{\circ} \mathrm{C}\right.$ ). The supernatant was removed, and cells were suspended in $115 \mu \mathrm{L}$ PBS. Then, $50 \mu \mathrm{L}$ of each sample was transferred into glass crimp vials, $150 \mu \mathrm{L}$ of methanol with $2 \mathrm{w} / \mathrm{v} \% \mathrm{NaOH}$ solution was added to each cell suspension, and the samples were immediately frozen at $20{ }^{\circ} \mathrm{C}$. Before the analysis, the samples were incubated at $90{ }^{\circ} \mathrm{C}$ for $30 \mathrm{~min}$. After cooling the samples to room temperature, $400 \mu \mathrm{L}$ of methanol containing 13-15\% boron trifluoride was added, and the sample were incubated at $90{ }^{\circ} \mathrm{C}$ for $30 \mathrm{~min}$. After cooling, $200 \mu \mathrm{L}$ of saturated $\mathrm{NaCl}$ solution and $500 \mu \mathrm{L}$ of $\mathrm{n}$-hexane were added to the solution. FAMEs were extracted to the upper phase containing n-hexane. Then, $400 \mu \mathrm{L}$ of the upper phase was transferred to a glass vial and were 
evaporated to dryness in nitrogen flow. Finally, samples were resolved in $200 \mu \mathrm{L}$ of $\mathrm{n}$-hexane, and were transferred to vials for GC analysis.

\subsection{Determination of protein concentration}

After harvesting the cells, $15 \mu \mathrm{L}$ of the cell suspensions was removed for protein concentration determination. The lysis buffer contained $0.1 \% \mathrm{SDS}, 5 \mathrm{mM}$ EDTA, $150 \mathrm{mM} \mathrm{NaCl}$, $50 \mathrm{mM}$ Tris, $1 \%$ Tween $20,1 \mathrm{mM} \mathrm{Na} \mathrm{VO}_{4}, 1 \mathrm{mM}$ PMSF, $10 \mathrm{mM}$ benzamidine, $20 \mathrm{mM} \mathrm{NaF}, 1 \mathrm{mM}$ pNPP and protease inhibitor cocktail. The lysates were centrifuged with benchtop centrifuge (10 min, $\left.10000 \mathrm{rpm}, 4{ }^{\circ} \mathrm{C}\right)$. Protein concentration of the supernatant was measured with Pierce BCA Protein Kit Assay (Thermo Scientific) according to the manufacturer's recommendation.

\subsection{Chromatographic separation and detection of fatty acids}

FAs were separated in a Zebron ZB-88 capillary column (60 $\mathrm{m} \times 0.25 \mathrm{~mm}$ i.d., $0.20 \mu \mathrm{m}$ film thickness) by using a Shimadzu GC-2014 gas chromatograph equipped with a Shimadzu AOC-20s autosampler and a flame ionization detector (FID) and a Shimadzu GC Solution. For the separation, $1 \mu \mathrm{L}$ of each sample was injected. The carrier gas was hydrogen at $35 \mathrm{~cm} / \mathrm{s}$ flow rate with a purge flow of $3.0 \mathrm{~mL} / \mathrm{min}$, and the split-rate was 5 . The injector and detector temperature was set to $250{ }^{\circ} \mathrm{C}$, and the oven temperature was increased from $100{ }^{\circ} \mathrm{C}$ to $220^{\circ} \mathrm{C}$ at a ramp of $4{ }^{\circ} \mathrm{C} / \mathrm{min}$. For the mass spectrometric detection, a Shimadzu GCMS-QP2010 instrument was used.

\section{Results}

\subsection{GC-FID method development}

A fast single-step sample preparation method based on previously published articles has been applied in the present work [26]. The samples were prepared as described in Sections 2.4 and 2.5. After the saponification, esterification and extraction of lipids, the samples were evaporated and resolved in $200 \mu \mathrm{L}$ of $\mathrm{n}$-hexane. The evaporation and the resolution of the samples were needed because without this step, a dative bond is formed between the boron trifluoride from the samples and the nitrile-group of the stationary phase which causes the degradation of the column.

As mentioned before, a Zebron ZB-88 capillary column was chosen for the separation of saturated and cis- and trans-unsaturated FAMEs. Preliminary measurements with the presented sample preparation method were performed to get an overall view of the number and type of FAMEs in the samples. A Supelco 37 Component FAME Mix was used to determine the individual FAMEs in our samples. A GC-MS measurement was applied to identify the compounds corresponding each peak in the chromatogram of the standard mix. Comparing the two chromatograms, we could identify the compound corresponding each peak in our samples according to the retention times. However, one peak was not found in the FAME MIX, therefore, MS detection was used for the identification. According to the mass spectra, the compound in question was a monounsaturated methyl octadecanoate, but the exact position of the double bond could not be determined. Since one of the FAs used in the cell treatments was vaccenate, a C18:1, $\mathrm{t} \Delta 11$ methyl ester standard was injected. The retention time of the analyte and the vaccenate were the same so we assumed that the unknown peak derived from vaccenate.

Using this method, chromatographic separation of the 10 FAMEs could be achieved in 25 min (Fig. 1).

\subsection{GC-FID method validation}

The specificity was checked by carrying out the sample preparation method with solvent samples without cell suspension and by calculating the resolution value between the peaks. In our method, there was no peak with the same retention time as the analyzed FAMEs.

The resolution values were determined by using GC Solution software. Values of the standard solution with the largest concentration are shown in Table 1. The values in the table refer to the resolution of each peak compared to the previous one. As shown, the required 1.5 value was not reached in one case, between the elaidate and the vaccenate. However, it affects only the calibration but not the sample evaluation since there is no elaidate and vaccenate in one sample at the same time. Resolution values for the peaks in cell samples are presented in Table 2.

For the linearity measurements, we prepared standard solutions of FAME standards at eight different concentrations from 1 to $200 \mu \mathrm{g} / \mathrm{mL}$. Our method was linear in this

Table 1 Resolution values for the $200 \mu \mathrm{g} / \mathrm{mL}$ standard solution

\begin{tabular}{lc}
\hline Compound & Resolution \\
\hline $\mathrm{C} 16: 0$ & $\mathrm{n} / \mathrm{a}$ \\
$\mathrm{C} 16: 1, \mathrm{c} \Delta 9$ & 12.490 \\
$\mathrm{C} 18: 0$ & 26.930 \\
$\mathrm{C} 18: 1, \mathrm{t} \Delta 9$ & 5.374 \\
$\mathrm{C} 18: 1, \mathrm{t} \Delta 11$ & 1.038 \\
$\mathrm{C} 18: 1, \mathrm{c} \Delta 9$ & 2.037 \\
\hline
\end{tabular}




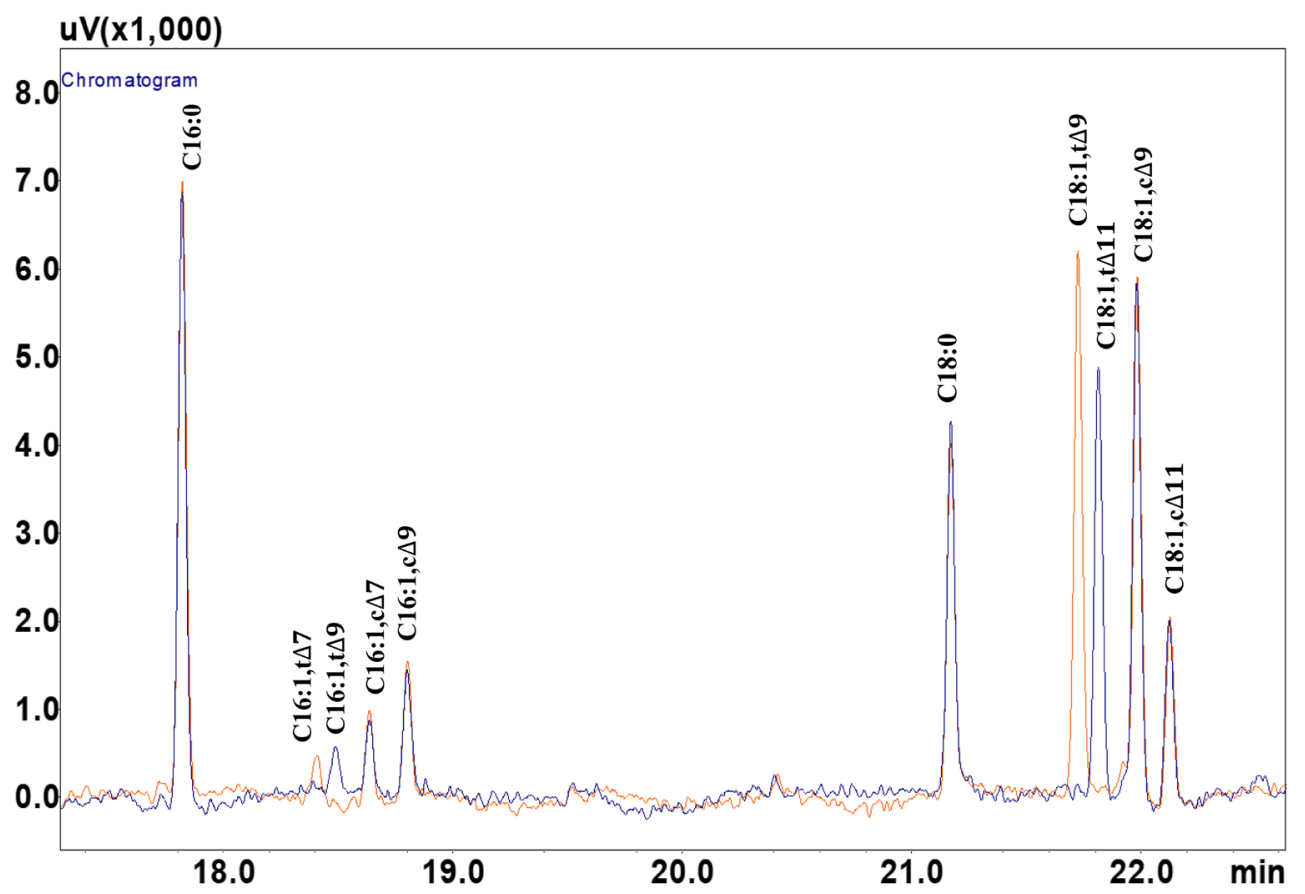

Fig. 1 Typical chromatograms of FAMEs in cell samples. RINm5F cells were incubated in a medium containing BSA-conjugated elaidate (red line) or vaccenate (blue line) at $50 \mu \mathrm{M}$. Medium was eliminated, and cell samples were withdrawn after $6 \mathrm{~h}$ long incubations. Esterified and non-esterified cellular fatty acids were derivatized to methyl esters, and they were separated on a Zebron ZB-88 capillary column with a (propyl-nitrile)-aril-dimethylpolysiloxane stationary phase $(60 \mathrm{~m} \times 0.25 \mathrm{~mm}$ i.d., $0.20 \mu \mathrm{m}$ film thickness). Ten saturated or cis- or trans-unsaturated FAMEs were detected by flame ionization. The presented FAMEs are the following: C16:0 - palmitate, C16:1, t $\Delta 7$ - trans $\Delta 7$ palmitoleate, C16:0 t $\Delta 9-\operatorname{trans} \Delta 9$ palmitoleate, C16:1, $\mathrm{c} \Delta 7$ - cis $\Delta 7$ palmitoleate, $\mathrm{C} 16: 0 \mathrm{c} \Delta 9$ - cis $\Delta 9$ palmitoleate, C18:0 - stearate, C18:1, t $\Delta 9$ - elaidate C18:1, t $\Delta 11$ - vaccenate, C18:1, $\mathrm{c} \Delta 9-$ oleate,

$\mathrm{C} 18: 1, \mathrm{c} \Delta 11$ - cis-vaccenate

Table 2 Resolution values for the peaks in cell samples

\begin{tabular}{|c|c|c|c|c|c|c|c|c|c|c|}
\hline Compound & C16:0 & $\mathrm{C} 16: 1, \mathrm{t} \Delta 7$ & $\mathrm{C} 16: 1, \mathrm{t} \Delta 9$ & $\mathrm{C} 16: 1, \mathrm{c} \Delta 7$ & $\mathrm{C} 16: 1, \mathrm{c} \Delta 9$ & C18:0 & $\mathrm{C} 18: 1, \mathrm{t} \Delta 9$ & $\begin{array}{c}\mathrm{C} 18: 1, \\
\mathrm{t} \Delta 11\end{array}$ & $\mathrm{C} 18: 1, \mathrm{c} \Delta 9$ & $\begin{array}{c}\mathrm{C} 18: 1, \\
\mathrm{c} \Delta 11\end{array}$ \\
\hline C16:0 & & 9.4 & 10.6 & 12.7 & & & & & & \\
\hline $\mathrm{C} 16: 1, \mathrm{t} \Delta 7$ & 9.4 & & & 3.6 & & & & & & \\
\hline $\mathrm{C} 16: 1, \mathrm{t} \Delta 9$ & 10.6 & & & 2.3 & & & & & & \\
\hline $\mathrm{C} 16: 1, \mathrm{c} \Delta 7$ & 12.7 & 3.6 & 2.3 & & 2.5 & & & & & \\
\hline $\mathrm{C} 16: 1, \mathrm{c} \Delta 9$ & & & & 2.5 & & 36.2 & & & & \\
\hline C18:0 & & & 97 & & 36.2 & & 8.6 & 10.0 & 12.8 & \\
\hline $\mathrm{C} 18: 1, \mathrm{t} \Delta 9$ & & & & & & 8.6 & & & 4.0 & \\
\hline $\mathrm{C} 18: 1, \mathrm{t} \Delta 11$ & & & & & & 10.0 & & & 2.6 & \\
\hline $\mathrm{C} 18: 1, \mathrm{c} \Delta 9$ & & & & & & 12.8 & 4.0 & 2.6 & & 2.2 \\
\hline $\mathrm{C} 18: 1, \mathrm{c} \Delta 11$ & & & & & & & & & 2.2 & \\
\hline
\end{tabular}

concentration range with an $\mathrm{R}^{2}=0.998$ for each compound. In the blank solution, no peak was detected with the retention time of analytes. To calculate lower limits of detection (LOD) and lower limits of quantitation (LOQ), three noise peaks were integrated, and from the mean values and the calibration curves were calculated. LODs was $0.1 \mu \mathrm{g} / \mathrm{mL}$ for each standard and the LOQs were between $0.2-0.5 \mu \mathrm{g} / \mathrm{mL}$.

Precision of retention time and peak area was investigated by repeated injections $(\mathrm{n}=5)$ of the same, $10 \mu \mathrm{g} / \mathrm{mL}$ for each FAME standard solution (Table 3). The relative standard deviations were $<5 \%$ for the retention times and for the peak areas as well. To evaluate the precision of the method, three standard solutions from each type of investigated compound (dipalmitoyl-glycerol for DGs, cis-palmitoleate for non-esterified FAs, stearoyl-sphingosine for ceramides and trioleoyl-glycerol for TGs) were prepared and injected (Table 4). For all investigated compounds, the standard deviation was not more than $6 \%$. 
Table 3 Precision of retention times and peak areas

\begin{tabular}{lcccc}
\hline \multirow{2}{*}{ Compound } & \multicolumn{2}{c}{ Retention time } & \multicolumn{2}{c}{ Peak area } \\
\cline { 2 - 5 } & $\begin{array}{c}\text { Mean } \\
{[\mathrm{min}]}\end{array}$ & RSD [\%] & $\begin{array}{l}\text { Mean } \\
{[\mu \mathrm{H}]}\end{array}$ & RSD [\%] \\
\hline $\mathrm{C} 16: 0$ & 17.767 & 0.006 & 30352 & 3.99 \\
$\mathrm{C} 16: 1, \mathrm{c} \Delta 9$ & 18.748 & 0.007 & 25357 & 3.91 \\
$\mathrm{C} 18: 0$ & 21.115 & 0.004 & 32773 & 3.83 \\
$\mathrm{C} 18: 1, \mathrm{t} \Delta 9$ & 21.666 & 0.004 & 23560 & 3.76 \\
$\mathrm{C} 18: 1, \mathrm{t} \Delta 11$ & 21.757 & 0.005 & 19832 & 4.11 \\
$\mathrm{C} 18: 1, \mathrm{c} \Delta 9$ & 21.925 & 0.006 & 24945 & 3.79 \\
\hline
\end{tabular}

Table 4 Method precision. Precision of the retention time and the peak area was determined by repeated injection of the same standard solution for each FAME solution

\begin{tabular}{lcc}
\hline Compound & $\begin{array}{c}\text { Concentration } \\
{[\mu \mathrm{g} / \mathrm{mL}]}\end{array}$ & RSD [\%] \\
\hline Diacyl-glycerol C16:0 & 22.30 & 0.46 \\
Non-esterified fatty acid C16:1, c $\Delta 9$ & 6.03 & 1.81 \\
Ceramide C18:0 & 12.46 & 3.33 \\
Triacyl-glycerol C18:1, c $\Delta 9$ & 37.23 & 5.07 \\
\hline
\end{tabular}

To determine robustness, three parameters of the chromatographic method (temperature ramp, flow rate of the carrier gas, oven temperature) were changed in two directions each. During the ramping of the temperature, 3 and $5^{\circ} \mathrm{C} / \mathrm{min}$ was used instead of $4{ }^{\circ} \mathrm{C} / \mathrm{min}$; the flow rate of the carrier gas was changed to 34 and $36 \mathrm{~cm} / \mathrm{s}$, and the oven temperature was set to $98{ }^{\circ} \mathrm{C}$ and $102{ }^{\circ} \mathrm{C}$ from $100{ }^{\circ} \mathrm{C}$. The determined concentrations after the changes are presented in Table 5.

Recovery rate of the sample preparation method was determined regarding four types of lipids, methyl-palmitoleate for non-esterified FAs, dipalmitoyl-glycerol for DGs, stearoyl-sphingosine for ceramides and trioleoyl-glycerol for TGs. For the stock and spiking solutions, standards were weighed in $2.00 \mathrm{~mL}$ volumetric flasks, and $200 \mu \mathrm{L}$ of chloroform was added to achieve the complete dissolution of all lipids, then methanol was used to fill the flask. The concentrations of the spiking solutions are shown in Table 6.
First, $10 \mu \mathrm{L}-10 \mu \mathrm{L}$ of spiking solution was added to the samples containing $50 \mu \mathrm{L}$ of cell suspension and $150 \mu \mathrm{L}$ of $\mathrm{NaOH}-$ methanol mix, or to samples containing $100 \mu \mathrm{L}$ of standard solution and $100 \mu \mathrm{L}$ of $\mathrm{NaOH}-$ methanol mix. The sample preparation method was carried out on three unspiked cell samples, three spiked cell samples (Table 6) and six standard solution sample (Table 7).

\subsection{Incorporation of fatty acids into cultured insulinoma cells}

The FA metabolism is a major determinant of pancreatic $\beta$ cell functions, and also a key stress factor in obesity, which can deteriorate insulin secretion. Our optimized analytical method was therefore applied to study the incorporation of various FAs into RINm5F rat insulinoma cells with special emphasis on two TFAs, i.e. elaidate and vaccenate, which had not been thoroughly investigated in spite of their evident medical importance. Cells were treated with BSA-conjugated palmitate, oleate, elaidate and vaccenate $(50 \mu \mathrm{M})$, and alterations in the cellular FA profiles were determined in samples prepared after $6 \mathrm{~h}$ incubation. It was revealed that all of the four FAs added to the medium were efficiently internalized by the cells, and the treatments caused an obvious elevation of total FA contents (Fig. 2).

Treatment with the saturated C16:0 palmitate resulted in a major change of the pattern, as it accumulated remarkably (its level doubled to $61 \mu \mathrm{g} / \mathrm{mg}$ protein), and it also led to a build-up of $C 16: 1, c \Delta 9$ palmitoleate and $C 18: 0$ stearate in the cells (by $2 \mu \mathrm{g} / \mathrm{mg}$ protein and by $4 \mu \mathrm{g} / \mathrm{mg}$ protein, respectively). Increase of the concentration of the latter two derivatives is evidently due to intracellular desaturation and elongation processes (Fig. 2). The endogenous cis unsaturated C18:1, c $\Delta 9$ oleate was also internalized effectively, and its concentration increased from $27.57 \pm 1.87$ (control) to $53.41 \pm$ 7.65 (oleate-treated) $\mu \mathrm{g} / \mathrm{mg}$ protein. There was no alteration in the concentration of $\mathrm{C} 16: 1, \mathrm{c} \Delta 7$, the intermediate of

Table 5 Measured concentrations in the determination of robustness. Three parameters of the chromatographic separation were changed in two directions each, then the concentration of the FAMEs were determined

\begin{tabular}{|c|c|c|c|c|c|c|}
\hline \multirow{2}{*}{ Compound } & \multicolumn{6}{|c|}{$\mathrm{RSD}[\%]$} \\
\hline & $3{ }^{\circ} \mathrm{C} / \mathrm{min}$ & $5^{\circ} \mathrm{C} / \mathrm{min}$ & $34 \mathrm{~cm} / \mathrm{sec}$ & $36 \mathrm{~cm} / \mathrm{sec}$ & $98^{\circ} \mathrm{C}$ & $102^{\circ} \mathrm{C}$ \\
\hline C16:0 & 6.17 & 5.57 & 5.62 & 3.60 & 7.90 & 2.90 \\
\hline $\mathrm{C} 16: 1, \mathrm{c} \Delta 9$ & 6.24 & 5.63 & 5.57 & 3.60 & 8.16 & 3.02 \\
\hline C18:0 & 6.34 & 5.72 & 5.73 & 3.66 & 7.64 & 2.88 \\
\hline $\mathrm{C} 18: 1, \mathrm{t} \Delta 9$ & 6.45 & 5.63 & 5.80 & 3.62 & 7.97 & 3.02 \\
\hline $\mathrm{C} 18: 1, \mathrm{t} \Delta 11$ & 6.61 & 5.83 & 5.37 & 3.50 & 7.22 & 2.70 \\
\hline $\mathrm{C} 18: 1, \mathrm{c} \Delta 9$ & 6.68 & 5.66 & 5.47 & 3.62 & 7.65 & 2.71 \\
\hline
\end{tabular}


Table 6 Recovery measurements for cell samples. First, $10 \mu \mathrm{L}$ of spiking solution was added to the samples containing $50 \mu \mathrm{L}$ of cell suspension and $150 \mu \mathrm{L}$ of $\mathrm{NaOH}-m e t h a n o l ~ m i x$, then the sample preparation was carried out, and the concentrations were determined

\begin{tabular}{lccccccc}
\hline \multirow{2}{*}{ Compound } & \multicolumn{2}{c}{ Unspiked cells } & \multicolumn{2}{c}{ Spiked cells } & \multicolumn{2}{c}{$\Delta \mathrm{C}(\alpha=100 \%)$} \\
\cline { 2 - 5 }$[\mu \mathrm{g} / \mathrm{mL}]$ & $\mathrm{C}[\mu \mathrm{g} / \mathrm{mL}]$ & Recovery [\%] \\
\hline Diacyl-glycerol 16:0 & 22.30 & 0.46 & 28.08 & 1.88 & 6.08 & 5.78 & 95 \\
Non-esterified fatty acid 16:1, c $\Delta 9$ & 6.03 & 1.81 & 20.77 & 1.88 & 17.94 & 14.73 & 82 \\
Ceramide C18:0 & 12.46 & 3.33 & 15.34 & 1.69 & 2.95 & 2.88 & 97 \\
Triacyl-glycerol C18:1, c $\Delta 9$ & 37.23 & 5.07 & 48.17 & 0.90 & 11.45 & 10.94 & 96 \\
\hline
\end{tabular}

Table 7 Recovery measurements for standard solutions. First, $10 \mu \mathrm{L}$ of spiking solution was added to the samples containing $100 \mu \mathrm{L}$ of standard solution and $100 \mu \mathrm{L}$ of $\mathrm{NaOH}$-methanol mix. then the sample preparation was carried out, and the concentrations were determined

\begin{tabular}{|c|c|c|c|c|c|}
\hline Compound & Mass in $100 \mu \mathrm{L}[\mu \mathrm{g}]$ & $\mathrm{C} 100 \% *[\mu \mathrm{g} / \mathrm{mL}]$ & $\begin{array}{l}\text { Measured concentration } \\
{[\mu \mathrm{g} / \mathrm{mL}]}\end{array}$ & $\mathrm{RSD} \%$ & Recovery [\%] \\
\hline Diacyl-glycerol 16:0 & 3.04 & 12.17 & 10.91 & 4.92 & 90 \\
\hline Non-esterified fatty acid $16: 1, \mathrm{c} \Delta 9$ & 8.97 & 35.52 & 35.52 & 2.35 & 99 \\
\hline Ceramide C18:0 & 1.48 & 5.91 & 5.31 & 8.32 & 90 \\
\hline Triacyl-glycerol C18:1, c $\Delta 9$ & 5.73 & 22.90 & 21.46 & 6.09 & 94 \\
\hline
\end{tabular}

*In case of a $100 \%$ conversion during the esterification step.

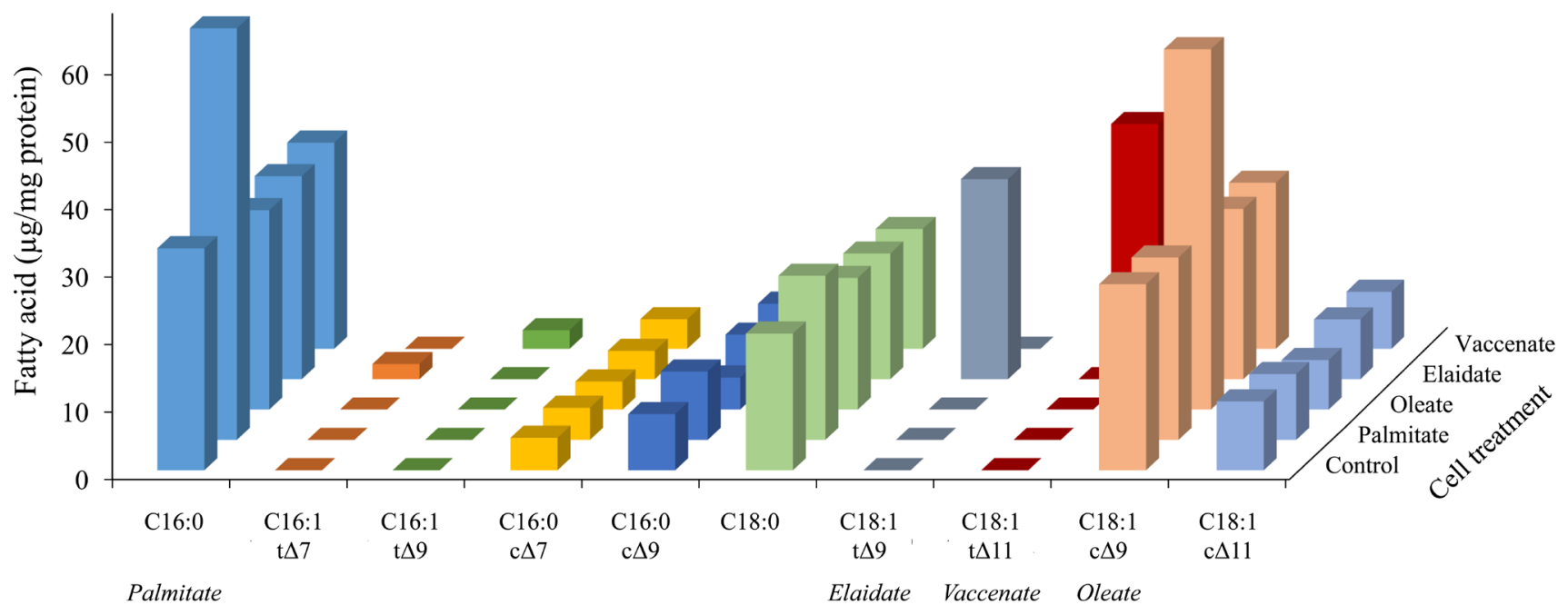

Fig 2 Fatty acid profile of the cells. Cells were incubated in a medium containing FA-free BSA (Control) or BSA-conjugated palmitate, oleate, elaidate or vaccenate $(50 \mu \mathrm{M})$ as indicated. Medium was eliminated, and cell samples were withdrawn after $6 \mathrm{~h}$ long incubation. The amount of $10 \mathrm{saturated}$ and mono-unsaturated FAs was measured by GC-FID after saponification and methylation, and the results were normalized to the total protein content of the samples. Data are shown as mean values \pm S.D.; $n=9$. C16:1, $\mathrm{c} \Delta 9$ (palmitoleate) is the desaturation product of palmitate, and C18:0 (stearate) is the elongation product of palmitate; $\mathrm{C} 16: 1, \mathrm{t} \Delta 7$ (trans $\Delta 7$ palmitoleate) is an intermediate of the $\beta$-oxidation of elaidate; $\mathrm{C} 16: 1, \mathrm{t} \Delta 9$ (trans $\Delta 9$ palmitoleate) is an intermediate of the $\beta$-oxidation of vaccenate.

oleate degradation after one cycle of $\beta$-oxidation; however, the concentration of $\mathrm{C} 16: 1, \mathrm{c} \Delta 9$ palmitoleate, the product of palmitate desaturation, decreased from $8.32 \pm 1.31$ (control) to $4.74 \pm 1.13$ (oleate-treated) $\mu \mathrm{g} / \mathrm{mg}$ protein (Fig. 2), which indicates a decreased desaturase activity.

Cellular levels of the two investigated TFAs increased similarly to that of oleate but they started from zero as FAs containing trans double bonds are not endogenous in the human and animal organisms (Fig. 2). A marked accumulation of the intermediates of elaidate and vaccenate Boxidation, C16:1, $\mathrm{t} \Delta 7(2.24 \pm 0.58 \mu \mathrm{g} / \mathrm{mg}$ protein; in elaidate-treated) and C16:1, t $\Delta 9(2.76 \pm 0.59 \mu \mathrm{g} / \mathrm{mg}$ protein; in vaccenate-treated), respectively was also seen in the appropriate samples (Fig. 2).

\section{Discussion}

Most of the cells are provided with FAs from the circulatory system. Plasma lipoproteins, such as VLDL and chylomicron 
carry liver-derived endogenous and intestine-derived exogenous FAs esterified in triglycerides, respectively. These FAs are liberated in the tissue capillaries and taken up as non-esterified FAs by the parenchymal cells. In addition, non-esterified, so-called free FAs are adsorbed to serum albumin, and they are also available for cellular uptake. Pathologies associated to high-fat diet and obesity provide overwhelming evidence that extensive FA supply can severely disturb cellular metabolism and signaling, which leads to dysfunction (lipotoxicity) or even cell death (lipoapoptosis).

It has been also repeatedly demonstrated that saturated FAs (e.g. palmitate) cause a greater damage in the cells compared to cis unsaturated FAs (e.g. oleate), and this is partly due to different efficiency of incorporation of the two FA species into complex lipids [17, 18, 31]. There is a special group of FAs, however, which is growingly present in the diet, and has been shown to have important health effects, yet its metabolism in mammalian cells has not been properly investigated. This is the group of trans unsaturated FAs, which can derive from meat and dairy products of ruminants or from industrially processed vegetable oils. Controversial studies have been published on in vivo health effects of TFAs [32-34]; and still very little in vitro data are available regarding the incorporation of TFAs into complex lipids or their intracellular degradation $[17,18]$.

In this article, we demonstrate the development of a GC-FID method, which is suitable for the separation and determination of the metabolites of the major saturated and cis or trans unsaturated FAs. The fast sample preparation method combines the lipid extraction from the sample and the lipid methylation into one single step followed by the evaporation of the solution which is essential to avoid the degradation of the stationary phase. The selected, biologically most relevant FAs, which are saturated FAs and positional and configurational isomers of mono-unsaturated FAs, are separated within a 25-min-long chromatographic process. The peaks were identified with a FAME Mix standard together with a vaccenate standard solution and by mass spectrometric detection. The quantification was performed using calibration curves, which were made from standard solutions.

In the validation process we proved that our method is specific and robust. The peak resolution values were higher than the expected 1.5, except in case of elaidate and vaccenate. However, this does not cause any problem in the measurements, provided that elaidate and vaccenate are not simultaneously present in the samples, as is often the case. The lower limit of detection was $0.1 \mu \mathrm{g} / \mathrm{mL}$ for all FAMEs while the lower limits of quantitation were between 0.2 and $0.5 \mu \mathrm{g} / \mathrm{mL}$. Regarding the precision and accuracy, the standard deviation was below $10 \%$ in all cases. Our method is linear in the range between 1-200 $\mu \mathrm{g} /$ $\mathrm{mL}$. Recoveries for diacyl-glycerols, triacyl-glycerols and ceramides were above $95 \%$; for non-esterified FAs, this value was $82 \%$, which is still adequate for applications using biological samples.

Our experiments on FA-treated cells showed the expected increase in the concentrations of the FAs administered, as well as of some metabolic derivatives. The results also indicated some differences between the metabolic features of cis and trans FAs. The products of elongation and desaturation of palmitate were detected, which is a clear sign of an intense metabolism of palmitate in the viable cells used in our experiments. Increased concentration of trans-palmitoleate $(\mathrm{C} 16: 1, \mathrm{t} \Delta 7)$ and its positional isomer $(\mathrm{C} 16: 1, \mathrm{t} \Delta 9)$ were found, which are the $\beta$-oxidation products of elaidate and vaccenate, respectively. However, the increase in the concentration of the analogous intermediate of oleate degradation was not observed in our experiments. This phenomenon might indicate a different affinity of mitochondrial long-chain acyl-CoA dehydrogenase (LCAD) enzyme to unsaturated FAs of cis or trans configuration. In accordance to our findings, $\mathrm{Yu}$ et al. demonstrated the difference in the affinity of 5-trans-tetradecenoyl-CoA and 5-cis-tetradecenoyl-CoA to LCAD, which might be responsible for the poor oxidation of elaidate compered to oleate [35]. Since the different efficiency of oxidation likely affects the intensity of FA utilization in diverse anabolic pathways, and hence the extent of toxicity, the observed phenomenon deserves further investigation.

\section{Acknowledgement}

We thank Ms. Valéria Mile for her valuable technical assistance. This work was supported by the Hungarian National Research, Development and Innovation Office (NKFIH grant number: K 125201) and by the Higher Education Excellence Program of the Ministry of Human Capacities in the frame of Biotechnology research area of Budapest University of Technology and Economics (BME FIKP-BIO). Anna Somogyi is a grantee of the ÚNKP19-3-I-SE-86 New National Excellence Program of the Ministry for Innovation and Technology.

\section{Conflict of interest}

The authors declare that they have no conflict of interest. 


\section{References}

[1] Cooper, D. E., Young, P. A., Klett, E. L., Coleman, R. A. "Physiological Consequences of Compartmentalized Acyl-CoA Metabolism", The Journal of Biological Chemistry, 290(33), pp. 20023-20031, 2015.

https://doi.org/10.1074/jbc.R115.663260

[2] El Kady, S. A., Abd El Gawwad, A. I., Kassem, A. E., Hamed, M. I., Rabie, M. M., Lásztity, R. "Effect of different alkali concentrations during the refining process on the fatty acid composition of sunflower and soybean oils", Periodica Polytechnica Chemical Engineering, 38(3-4), pp. 147-152, 1994.

[3] Dhaygude, V., Soós, A., Somogyi, L. "Solidification of the Blends of Fully Hydrogenated Coconut Oil and Non-hydrogenated Coconut Oil", Periodica Polytechnica Chemical Engineering, 62(1), pp. 123-127, 2018.

https://doi.org/10.3311/PPch.9638

[4] Gershuni, V. M. "Saturated Fat: Part of a Healthy Diet", Current Nutrition Reports, 7, pp. 85-96, 2018.

https://doi.org/10.1007/s13668-018-0238-X

[5] Zámbó, V., Simon-Szabó, L., Szelényi, P., Kereszturi, É., Bánhegyi, G., Csala, M. "Lipotoxicity in the liver", World Journal of Hepatology, 5(10), pp. 550-557, 2013.

https://doi.org/10.4254/wjh.v5.i10.550

[6] Jenkins, T. C. "Lipid Metabolism in the Rumen", Journal of Dairy Science, 76(12), pp. 3851-3863, 1993.

https://doi.org/10.3168/jds.S0022-0302(93)77727-9

[7] Kuhnt, K., Baehr, M., Rohrer, C., Jahreis, G. "Trans fatty acid isomers and the trans-9/trans-11 index in fat containing foods", European Journal of Lipid Science and Technology, 113(10), pp. 1281-1292, 2011.

https://doi.org/10.1002/ejlt.201100037

[8] Salmerón, J., Hu, F. B., Manson, J. E., Stampfer, M. J., Colditz, G. A., Rimm, E. B., Willett, W. C. "Dietary fat intake and risk of type 2 diabetes in women", The American Journal of Clinical Nutrition, 73(6), pp. 1019-1026, 2001.

https://oi.org/10.1093/ajen/73.6.1019

[9] Stampfer, M. J., Sacks, F. M., Salvini, S., Willett, W. C., Hennekens, C. H. "A Prospective Study of Cholesterol, Apolipoproteins, and the Risk of Myocardial Infarction", The New England Journal of Medicine, 325(6), pp. 373-381, 1991. https://oi.org/10.1056/nejm199108083250601

[10] Lopez-Garcia, E., Schulze, M. B., Meigs, J. B., Manson, J. A. E., Rifai, N., Stampfer, M. J., Willett, W. C., Hu, F. B. "Consumption of Trans Fatty Acids Is Related to Plasma Biomarkers of Inflammation and Endothelial Dysfunction", The Journal of Nutrition, 135(3), pp. 562-566, 2005. https://doi.org/10.1093/jn/135.3.562

[11] Mozaffarian, D., Rimm, E. B., King, I. B., Lawler, R. L., McDonald, G. B., Levy, W. C. "trans Fatty Acids and Systemic Inflammation in Heart Failure", The American Journal of Clinical Nutrition, 80(6), 1521-1525, 2004.

https://doi.org/10.1093/ajen/80.6.1521

[12] Astrup, A., Dyerberg, J., Selleck, M., Stender, S. "Nutrition transition and its relationship to the development of obesity and related chronic diseases", Obesity Reviews, 9(s1), pp. 48-52, 2008. https://doi.org/10.1111/j.1467-789X.2007.00438.x
[13] U.S. Food \& Drug Administration "Final Determination Regarding Partially Hydrogenated Oils (Removing Trans Fat)" [online] Available at: https://www.fda.gov/food/food-additives-petitions/ final-determination-regarding-partially-hydrogenated-oils-removing-trans-fat [Assessed: 19 July 2019]

[14] Christiansen, E., Schnider, S., Palmvig, B., Tauber-Lassen, E., Pedersen, O. "Intake of a Diet High in Trans Monounsaturated Fatty Acids or Saturated Fatty Acids: Effects on postprandial insulinemia and glycemia in obese patients with NIDDM", Diabetes Care, 20(5), pp. 881-887, 1997. https://doi.org/10.2337/diacare.20.5.881

[15] Louheranta, A. M., Turpeinen, A. K., Vidgren, H. M., Schwab, U. S., Uusitupa, M. I. J. "A high-trans fatty acid diet and insulin sensitivity in young healthy women", Metabolism, 48(7), pp. 870-875, 1999. https://doi.org/10.1016/s0026-0495(99)90221-4

[16] Lovejoy, J. C., Smith, S. R., Champagne, C. M., Most, M. M., Lefevre, M., DeLany, J. P., Denkins, Y. M., Rood, J. C., Veldhuis, J., Bray, G. A. "Effects of Diets Enriched in Saturated (Palmitic), Monounsaturated (Oleic), or trans (Elaidic) Fatty Acids on Insulin Sensitivity and Substrate Oxidation in Healthy Adults", Diabetes Care, 25(8), pp. 1283-1288, 2002. https://doi.org/10.2337/diacare.25.8.1283

[17] Sarnyai, F., Berinkeiné Donkó, M., Mátyási, J., Gór-Nagy, Zs., Marczi, I., Simon-Szabó, L., Zámbó, V., Somogyi, A., Csizmadia, T., Lőw, P., Szelényi, P., Kereszturi, É., Tóth, B., Csala, M. "Cellular toxicity of dietary trans fatty acids and its correlation with ceramide and diglyceride accumulation", Food and Chemical Toxicology, 124, pp. 324-335, 2019. https://doi.org/10.1016/j.fct.2018.12.022

[18] Sarnyai, F., Somogyi, A., Gór-Nagy, Zs., Zámbó, V., Szelényi, P., Mátyási, J., Simon-Szabó, L., Kereszturi, É., Tóth, B., Csala, M. "Effect of cis- and trans-Monounsaturated Fatty Acids on Palmitate Toxicity and on Palmitate-induced Accumulation of Ceramides and Diglycerides", International Journal of Molecular Sciences, 21(7), Article No. 2626, 2020. https://doi.org/10.3390/ijms21072626

[19] Folch, J., Lees, M., Sloane Stanley, G. H. "A simple method for the isolation and purification of total lipides from animal tissues", The Journal of Biological Chemistry, 226(1), pp. 497-509, 1957.

[20] Bligh, E. G., Dyer, W. J. "A rapid method of total lipid extraction and purification", Canadian Journal of Biochemistry and Physiology, 37(8), pp. 911-917, 1959.

https://doi.org/10.1139/059-099

[21] Matyash, V., Liebisch, G., Kurzchalia, T. V., Shevchenko, A., Schwudke, D. "Lipid extraction by methyl-tert-butyl ether for high-throughput lipidomics", Journal of Lipid Research, 49(5), pp. 1137-1146, 2008. https://doi.org/10.1194/jlr.D700041-JLR200

[22] Ostermann, A. I., Müller, M., Willenberg, I., Schebb, N. H. "Determining the fatty acid composition in plasma and tissues as fatty acid methyl esters using gas chromatography - a comparison of different derivatization and extraction procedures", Prostaglandins, Leukotrienes and Essential Fatty Acids, 91(6), pp. 235-241, 2014.

https://doi.org/10.1016/j.plefa.2014.10.002 
[23] Rodrigues, R. O., Costa, H., Lima, R., Amaral, J. S. "Simple Methodology for the Quantitative Analysis of Fatty Acids in Human Red Blood Cells", Chromatographia, 78, pp. 1271-1281, 2015. https://doi.org/10.1007/s10337-015-2947-2

[24] Lepage, G., Roy, C. C. "Direct transesterification of all classes of lipids in a one-step reaction", Journal of Lipid Research, 27(1), pp. 114-120, 1986. https://doi.org/10.1016/S0022-2275(20)38861-1

[25] Kang, J. X., Wang, J. "A simplified method for analysis of polyunsaturated fatty acids", BMC Biochemistry, 6, Article No. 5, 2005. https://doi.org/10.1186/1471-2091-6-5

[26] Baticz, O., Tömösközi, S., Vida, L. "Concentrations of citrate and ketone bodies in cow's raw milk", Periodica Polytechnica Chemical Engineering, 46(1-2), pp. 93-104, 2002.

[27] Kovács, A. G., Szöllősi, A., Szöllősi, D., Panyik, I. A., Nagygyörgy, L., Hoschke, Á., Nguyen, Q. D. "Classification and Identification of Three Vintage Designated Hungarian Spirits by Their Volatile Compounds", Periodica Polytechnica Chemical Engineering, 62(2), pp. 175-181, 2018. https://doi.org/10.3311/PPch.11078

[28] Somogyi, L., Gorka, Á., Soós, A., Badak-Kerti, K., KóczánManninger, K., Szedljak, I. "Effect of Immersed Herbs on the Oxidative Stability of Edible Oils", Periodica Polytechnica Chemical Engineering, 59(4), pp. 272-276, 2015. https://doi.org/10.3311/PPch.7571

[29] Nyerges, Gy., Mátyási, J., Balla, J. "Investigation and Comparison of $5 \%$ Diphenyl - $95 \%$ Dimethyl Polysiloxane Capillary Columns", Periodica Polytechnica Chemical Engineering, 64(4), pp. 430-436, 2020.

https://doi.org/10.3311/PPch.15289
[30] Wolff, L. R. "Resolution of Linolenic Acid Geometrical Isomers by Gas-Liquid Chromatography on a Capillary Column Coated with a 100\% Cyanopropyl Polysiloxane Film (CP ${ }^{\mathrm{TM}}$ Sil 88)", Journal of Chromatographic Science, 30(1), pp. 17-22, 1992. https://doi.org/10.1093/chromsci/30.1.17

[31] Somogyi, A., Berinkeiné Donkó, M., Sarnyai, F., Becskereki, G., Csala, M., Tóth, B. "Simultaneous Quantitative Determination of Different Ceramide and Diacylglycerol Species in Cultured Cells by Using Liquid Chromatography-Electrospray Tandem Mass Spectrometry", Periodica Polytechnica Chemical Engineering, 64(4), pp. 421-429, 2020. https://doi.org/10.3311/PPch.15357

[32] Mozaffarian, D., Katan, M. B., Ascherio, A., Stampfer, M. J., Willett, W. C. "Trans Fatty Acids and Cardiovascular Disease", The New England Journal of Medicine, 354(15), pp. 1601-1613, 2006. https://oi.org/10.1056/NEJMra054035

[33] Kleber, M. E., Delgado, G. E., Lorkowski, S., März, W., von Schacky, C. "Trans-fatty acids and mortality in patients referred for coronary angiography: The Ludwigshafen Risk and Cardiovascular Health Study", European Heart Journal, 37(13), pp. 1072-1078, 2016. https://doi.org/10.1093/eurheartj/ehv446

[34] Ginter, E., Simko, V. "New data on harmful effects of trans-fatty acids", Bratislava Medical Journal, 117(5), pp. 251-253, 2016. https://doi.org/10.4149/bll_2016_048

[35] Yu, W., Liang, X., Ensenauer, R. E., Vockley, J., Sweetman, L., Schulz, H. "Leaky beta-oxidation of a trans-fatty acid: incomplete beta-oxidation of elaidic acid is due to the accumulation of 5-trans-tetradecenoyl-CoA and its hydrolysis and conversion to 5-trans-tetradecenoylcarnitine in the matrix of rat mitochondria", Journal of Biological Chemistry, 279(50), pp. 52160-52167, 2004. https://doi.org/10.1074/jbc.M409640200 